\title{
Integration as Condition of Sustainable Development of Society and Education
}

\author{
A.M. Mityaeva \\ Chair of social management and conflictology \\ Orel State University \\ Orel, Russian Federation \\ caercauthor@yahoo.com
}

\author{
S.N. Fomina \\ Department of organization of work with the youth, \\ Russian State Social University \\ Moscow, Russian Federation \\ caercauthor@yahoo.com
}

\author{
A.M. Egorychev \\ Chair of social pedagogics, \\ Russian State Social University \\ Moscow, Russian Federation \\ caercauthor@yahoo.com
}

\author{
E.A. Khovanskaya \\ Chair of theory and methods of teaching \\ the Russian language and literature, \\ Orel State University \\ Orel, Russian Federation \\ caercauthor@yahoo.com
}

\author{
E.V. Mityaeva \\ Chair of social management and conflictology, \\ Orel State University \\ Orel, Russian Federation \\ caercauthor@yahoo.com
}

\begin{abstract}
The article deals with the process of formation and sustainable development of modern society and education in the 21st century. World processes of financial and economic internationalization, including the aspiration of many peoples and states for cooperation and interethnic interaction, first of all, are the result of integrating the development of the world community as a global social system and an education system. Integration is an important methodological category that determines the development of all institutions and structures of the state and society. Culture, education, economics, politics constitute a certain model determining the stable position and development of the world community, creation of prerequisites and social conditions for the full development of social institutions of the entire world community. The system of Russian education requires the elaboration of a new development methodology and assumes an increase in the share of the humanitarian component in the education system of all its levels; the return of the institution of education as the most important factor in the formation and development of society; change of orientations in the system of secondary and higher vocational education from the profile training of specialists (bachelors, masters, specialists) of all spheres of management of the Russian Federation to a broader professional level. Thus, economic, geopolitical, cultural, educational and scientific-educational processes predetermine tendencies and directions of the development of the educational paradigm, society as a whole.
\end{abstract}

Keywords-integration; human civilization; education system; noospheric development path.

\section{INTRODUCTION}

At the beginning of the XXI century, human civilization entered a new stage of its development which might be a difficult test for all peoples and states of the planet Earth.

With each new round of development, mankind acquires not only the experience of survival, but also the understanding of those trends and conditions that give rise to the impulse of further social and cultural progress, to building a more perfect society.

Being a huge social organism, having a high level of opportunities to choose its way of development, sufficient resources and potential for solving almost any task in building a social community of equal opportunities for all nations and peoples of the planet, human civilization, nevertheless, has a narrow horizon of social consciousness and prospects for its development today. There are several questions. What is the main condition for the sustainable development of human civilization? What social institutions determine the formation of public consciousness? What is the role of governance in the development of human civilization?

The accumulated vast historical experience of the destruction of cultures and civilizations (rebellions, revolutions, wars, natural disasters) has not given great practical results yet; it is not the basis for developing a new ideology of the existence of the nations of world civilization that would not allow evil and violence against a person, certain peoples and states. Just like hundreds years ago, the 
world ideology of livelihood is based on fanatic intolerance, misunderstanding and rejection of nations and countries that have their own national values and development priorities. Today, in the politics of the world community, there is rigid antagonism of political and cultural rejection of any people who have shown the desire to carry out state building on the basis of their historical traditions and values, the desire to live according to their own historical laws. All this generates ideological disagreement in almost all issues of international politics, creates a threat to existence and development of multipolar world [3, 4].

The beginning of the XXI century has shown that humanity has entered a completely new era, where the old proven ways of social organization of peoples and nations, small and large social groups, formation of systems of interethnic relationships and interactions no longer give the same results, do not satisfy the basic mass of working people of all countries and states of the planet Earth. Exacerbated social contradictions (social and economic inequality, poverty, national intolerance, religious fanaticism and terrorism, and many other things) show the inconsistency of the existing world ideology based on the priority of market values, the power of capital, unjust distribution of income, the hegemony of unipolar world. Profit, like a sacred idol, continues to be the main tool in solving almost all issues of the life organization of modern society, subordinating everything and everyone to the goals and senses of market economy, including education system as the most important institution for the development of society.

The economy of practically all developed countries, unfortunately, remains the target vector of the development of world civilization, subordinating to its ideology politics, science, education and culture, practically all social institutions, including the world of each person, defining goals and the meaning of life. As many modern researchers point out, there is a total process of destruction of the integrity of man, his true nature, which generates various kinds of social deviations, causes profound mental disorders (Kaznacheev V.P., Egorychev A.M., Subetto A.I., Lopukha A.D., Turchenko V.N. and others).

\section{METHODS}

\section{A. Theoretical basis}

In this turbulent and contradictory time, in a really crucial age for mankind, the role of the institution of education in the preparation of man and society for entering a new space of life, for building a just and safe society becomes unique. This thesis is predetermined by basic provisions that must be taken into account in a new historical dimension when adjusting state ideology, developing social institutions:

1. The development of the world community as a global social system combines two processes:

natural, connected with all historical experience, national tendencies, established historical realities (views, attitudes, traditions, national norms and stereotypes, value system). This process is constantly in conflict with constantly emerging trends and innovations. There is a natural, slow and contradictory process of development of the social world, its development and progress;

managed, connected with the conducted policy of the leading states of the world, conscious and purposeful influence on social processes in the world community. This process depends, first of all, on the level of development of public consciousness, integrated interests of all countries and peoples of the world community.

The analysis of the realities of the modern world order and its development shows that today there is an active process of integrating the indicated processes. Natural and controlled processes in their integrative essence determine the development of modern human civilization, including individual, small and large social institutions (groups, collectives, associations, ethnoses, nations, peoples).

It is necessary to note an important issue: the modern time is characterized by a sharp update and activation of the management system, which determines the development of almost all spheres of the life organization of man (his natural and social environment). To a greater extent, these changes begin to affect the system of national education.

1. The system of education is the priority social institution in the development of any national community and state, the bearer and creator of culture and information, as well as an important state tool for the formation of a person (new personality), his consciousness and outlook, professional orientation and professional development and the most important thing, education of his spiritual and moral foundations. Simultaneously, the education system is the greatest mechanism for managing the development of man and society in accordance with the goals (goals of state social policy).

Education is a rather autonomous system that acts as the bearer of historical meanings and values, traditions and principles of national culture, linking past, present and future of any national community, which does not allow destroying the national basis of statehood and society, historically given way of development. The education system acts as a mechanism for preserving national meanings and values, knowledge and traditions, accumulated and carefully preserved, their integration with the flow of new knowledge and values generated by new time, their transmission from generation to generation.

Education is a social institution that acts as: a mechanism for integrating the processes of upbringing, education and human development at all levels (preschool, school, vocational, additional); providing social and pedagogical assistance, support to every person throughout his life (continuous education); an instrument to stimulate the process of integrating individual into the national community, preparing for life in a multinational world community.

The processes of globalization, observed in world civilization, can be perceived as a powerful objective trend and process of the XXI century integration (natural and managed). This integration contains huge forces and energy, which can be both destructive and creative. 
Today, the result of such integration is, first of all, the world processes of financial and economic internationalization, including the desire of many peoples and states to cooperate and interethnic interaction.

In the studies of modern scientists, integration is an important methodological category that determines the development of all institutions and structures of the state and society (Bim-Bad B.M., Gershunsky B.S., Korolkov A.A., Losev A.F., Maksimova V.N., Malofeev N.N., Turchenko V.N., Egorychev A.M., Fomina S.N., Shamsutdinova D.V. and others). Integration in its actions solves the basic problem that determines the existence of world civilization in the $21 \mathrm{st}$ century: it provides certain integrity in the development of multinational world community.

It can be said that integration is the most important process and mechanism allowing one to combine efforts of various state and public systems of peoples and states of the world community for achieving any goals. The question is who manages and what purpose does he have?

\section{B. Models}

To understand the subject of this discussion, let us show the model of a stable position and development of the world civilization (Figure 1).

This model is an ideal in which all components are integrated into a complex system, have their own certain place and function. At the base of the pyramid, there is the basis culture of all mankind, which is a solid foundation on which the entire world civilization is built and developed.

Education - the main superstructure over the basis, which is the repository and translator of cultural and spiritual meanings and values to new generations, to every member of the community.

Culture and education are initially integrated by the whole logic of the development of a reasonable and spiritual person, by the meaning and logic given to humanity from above.

Economy - the superstructure that is created (should be created) on the basis of cultural national meanings and values of each specific nation. The mission and the goal of the economy of any state, proceeding from the peculiarities of its national culture, should have an orientation towards achieving the well-being of all members of society, without exception, building social and just society.

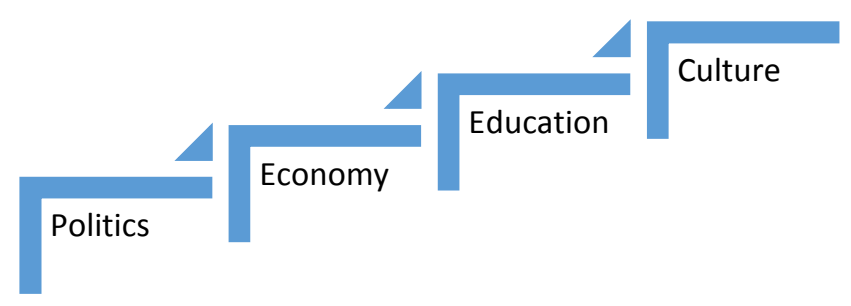

Fig. 1. Model of stable position and development of the world civilization
Politics is the highest level of the pyramid where the full integration of all meanings and values of the three lower levels (culture, education, economy) is expressed (should be expressed). The upper level is the supreme power, the system of managing the society. It is the state policy (economic, social, national, cultural, youth, agrarian, etc.) that is determining social mechanism that influences all spheres of society's life, well-being and sustainable development of the state and society.

The management of the process of cultural, educational and economic integration determines the creation of prerequisites and social conditions for the full development of the social institutions of the entire world community, the opportunities for all the peoples of the world to participate in the development of a new paradigm of the world order in the 21 st century.

Let us turn to the specifics of the development of the Russian state and society. Russia is a unique state with its history of birth, formation and development for thousands of years.

Domestic culture and education were born and developed in organic unity, integrated by the logic of the organization of the existential world of the tribal community of the Russian world. It is also natural that the Russian world accepted Orthodoxy as the spiritual basis for its further development. Russian culture and national education, being in organic unity with faith in the high meanings of life, created a unique history of Russian statehood, created a Russian person, formed the mentality of the people.

Forming the strategy of its development, Russia has always tried to rely on the basic foundations of the national culture - system of national education [3].

Let us mark the basic provisions of the national culture, which had a significant impact on the development of the Russian state and society, its social institutions, the system of national education and enlightening:

Russian idea, which embodied the spiritual aspirations of its great passionaries: Orthodox thinkers, statesmen, philosophers, scientists, writers, educators, enlighteners (Metropolitan of Kiev Ilarion, Soloviev V.S., Trubetskoi E.N., Rozanov V.V., Il'in I.A., Berdyaev N.A., Fedotov G.P. and others), as well as ordinary citizens-workers of Russia. The general meaning of the Russian idea was the development of Russia in high spiritual senses and values of the great Russian culture. The essence of the Russian idea coincides with the Christian transformation of life, building it on the basis of conciliarity, truth, goodness, beauty.

Russian statehood (cathedral), the feature of whose creation makes it unique. The experience of Russia is characterized by an organic continuity in the implementation of the state idea, which allowed solving all complex problems of domestic and foreign policy of the country properly. Russian religious philosopher Tikhomirov L.A. (1852-1923) in his main works ("Monarchic Statehood", "State, Freedom and Christianity"), on the basis of deep historical and philosophical analysis, came to the understanding that the conciliar system, which had been established in Russia, was 
deeper and fuller than any democracy, since conciliarity not only coordinates the will of the majority with the will of the minority, but also expands this consent in time on previous generations [4].

Orthodox Christianity at the head of the Russian Church. The spiritual influence of the Russian Orthodox Church on the development of Russian society and man was understood and supported by many enlighteners and philosophers (Zhukovsky V.A., Il'in I.A., Berdyaev N.A., Bolotov A.T., Bronzov A.A., Bulgakov S.N., Burachek S.A., Bukharev A.M. and others). Russian Orthodoxy since the birth determined the development of statehood, the formation of a Russian man, including the entire system of complex social relations in Russia.

Belikov V.D. and Chetverikova-Belikova S.I. write: "Orthodoxy is the ideological matrix in which Russia was cast, where church became a beacon of spiritual life and a measure of everyday behavior" [5, p. 3]. This was well understood by all the previous rulers of Russia, as well as all generations of Russian ancestors until the beginning of the 20th century (1917 - the beginning of a new history in the development of Russia).

Arguing about the role of the Orthodox Church in the history of the formation of the Russian state and society, Malkov G. remarks: "For more than a millennium of the historical life of Russia, it was proved in the most direct way that without the Christian system of spiritual and moral values, without evangelical "heaven" landmarks on the earth path of our Fatherland - he (neither a healthy state organism, nor truly civilized civil society) cannot be!" [6, p. 132].

The designated basic foundations of the national formation and development of Russian culture and civilization were integrated by the historical time and the peculiarity of the development of the Russian world, served as important bases in building the national education and the education system, filling it with meanings, values, traditions of the Russian culture, giving it a special identity, fully responding the mentality of Russian people.

At the present stage of the development of the world community, when the processes of globalization are on the scale, really comprehensive, embracing practically all states and peoples, education acquires new properties, characteristics, orientation. In this regard, it should be noted that:

1. Education turns into a continuous process, covers almost all stages of human ontogeny, acquires the character of its universal accompaniment throughout life. The concept of continuous education, announced in the XX century (50-60ies.), today acquires a special sound. Education begins to integrate organically all its steps, types and levels into a complex system that should provide a good opportunity to receive, update and replenish knowledge, skills and abilities throughout the life of a person, from pre-school childhood to old age. The present integration requires the correction of the goals and content of Russian education, its conformity both to the requirements of the new time, and to ensuring the necessary consistency and continuity of knowledge, skills and abilities at different stages and levels of the education system.

2. Education goes beyond national states, acquires more universal qualities and properties. There is a process of creating a single global educational space with common educational and professional standards, content and direction. The key problem of developed countries, united by the complex system of socio-economic interrelations and mutual relations, political alliances and cultural programs, is the task of "leveling" national educational standards and programs, bringing them to the necessary universality. The problem of leveling educational opportunities of all social groups, as well as individual citizens, their starting opportunities and free access to education is also acute.

3. The system of education, through its structures and mechanisms, gradually enters all institutions and structures of the state and society, creating conditions for the continuous improvement of a person, disclosing his creative potential, forming him as a person in accordance with the needs of a specific national community, state policy. The abovementioned facts actualize the role and significance of the institution of social pedagogy, which specialists are able to organize social and pedagogical activities systematically in almost all state and social institutions, structures, organizations and institutions of the country.

4. Education as a social system is more subject to the ideology of market economy. Its purpose and orientation, structure and content begin to be rigidly and purposefully submitted to the laws of market economy, ignoring high meanings and values of the human being world. There is a growing attention to the study of economic and legal disciplines, to the formation of a "person-function", "business and competitive", to the detriment of the spiritual and moral development of the individual. Appeared "curvature" in the purposes and content of domestic education, creates dangerous risks in the formation of a harmonious and broad-minded person, including the quality of his professional training.

5. In education, technology (educational, information, research, upbringing, communicative, etc.) plays an increasing role. The educational process develops the role of the professor as a carrier and an exponent of scientific culture and scientific information is pushed to the background. Fundamentalism as a basic principle in training specialists in higher education is gradually losing its priorities. It is replaced by a new format for training a specialist, where all efforts are focused on the formation of professional competencies according to rather narrow profile of professional training. There is a process of forming a "person-function", focused on the narrow direction in professional activity, possessing the appropriate qualities and properties.

6. At the same time, there is a general decline in the quality of mass education. The secondary school is influenced by the new time. The tendency to "strengthen the profile of secondary education" begins to be affirmed, and the share of specialized schools is increasing. At the same time, the prestige of the professions of the humanitarian profile is decreasing. Upbringing in educational activity as the most important social institution for preparing the younger 
generation for life and work, socialization and its integration into society, is pushed to the background more.

\section{RESULTS}

As one can see, the tendencies, properties and characteristics of modern education, mentioned above, have both positive and negative aspects in their development. Nevertheless, despite a number of negative trends observed in the system of modern education, it can be said that education as the most important social institution of the state and society, begins to be a priority in the ideology and politics of many developed countries of the world community. There is a general understanding of the role of education in the sustainable development of human civilization, its enormous influence on the process of integration of all structures and institutions of the world community (culture, science, politics, economy, etc.).

If one follows the logic of the development of the world civilization, then in the second half of the XXI century education will integrate greatly with all social institutions and structures of the state and society and become together with science that "geological force" (according to Vernadsky V.I.), which will determine the development of the world culture and civilization, any national community. The great scientist stated that mankind will enter the noosphere for sure - "the realm of the human mind" [7].

\section{DISCUSSION}

Almost all the social institutions and structures of the state and society depend on the level of development of education today. Although it is necessary to admit that today in Russia, the interaction of the modern education system with the main spheres, structures and institutions of the state and society is not very effective yet. Management of the system of domestic education, its development are extremely inefficient. All organized and ongoing reforms and modernization of the national education show low results for a new period (beginning in 1991). Moreover great historical educational experience is being destroyed and lost.

The onset of the information era, as well as the consideration of world trends, made it necessary to intensify the development of national education systems of developed and developing countries of the world community. There is an active process of adjusting national education systems, strengthening their material and technological base and modernizing the educational process. Serious changes in the state policy of developed countries regarding the development of national education systems are expected in the near future.

The concept of education is also expanding significantly, filled with new meanings and content. This is due to the development of the scientific and technological potential of the education system, to the increase of its role in organizing the vital activity of all spheres of society, to the active process of its integration with science, production, and the social sphere. This naturally led to the discovery of new specialties and activity profiles, as well as significant enrichment of the content of education, its access to a new theoretical and methodological level.
It is known, one of the most important factors determining the effectiveness of the educational system is its ability to educate (form, create, bring up) a person who will live and work in the future, meet all the emerging trends of the world community and the needs of a new era. "To educate" means to teach and bring up a person, prepare him for life and work for the benefit of family, people, country, taking into account all the meanings and values of the national culture.

Modern researchers point out that the education system must perceive and understand the perspective directions of the development of human civilization, its administrative and scientific-methodological potential (scientific schools and directions, upbringing and educational traditions), must meet the requirements of the time, meet its challenges professionally (Mardakhaev L.V., Fomina S.N., Bykov A.K., Sizikova V.V., Egorychev A.M. and others).

The upbringing and educational process of any level of the educational organization (preschool, general, secondary, professional, supreme, additional) should become the personification of the ongoing fundamental change in the development of man and society, filled with goals and content, meanings and values that correspond to the spirit of the coming era, its high standards to the person. The emerging new man must become the bearer and the exponent of a new ideology of life of the noosphere era, where spirituality and humanism will become the determining factor in the organization of national communities, the most complex system of interethnic interaction.

The practice shows that the system of domestic education requires the development of a new methodology for development $[8,9]$. The ineffective system of managing the national education, the low results of the ongoing reforms and modernizations, the widespread decline in the quality of education at all levels, all this indicates a disparity in the existing methodology underlying its organization, functioning and development, the goals and objectives of the Russian state, the logic of its historical development ways. It can be said that it does not match:

the challenges of the new time, the needs and dynamics of the developing country, the grand tasks that the Russian people will face in the near future;

the peculiarities of Russian culture, its meanings and values, the historical specifics of the development of statehood in Russia, the mentality of its great people.

The new methodology of management, functioning and development of domestic education presupposes the following:

1. Increasing the share of the humanitarian component in the education system of all its levels. Bringing all the necessary scientific disciplines to the system equilibrium determines educational programs and forms the basis of harmonious development of man. The formation of a person as an individual of high spiritual order assumes to return to the concept of "harmonious formation of personality forever". The main emphasis in preparing for the life of the younger generation should be determined not only by the logic of market relations (the development of some useful qualities that 
can be competitive and popular for a person), more logic of revealing the true essence of man, his infinite potential, the possibility of realizing his spiritual greatness. Only a person who is aware of himself as a great spiritual force, conscious of the catholicity in himself, is able to solve any problems.

2. The return of the institution of education in the domestic education system, to all its levels, to all educational organizations. Education should become an equitable direction in the education system, organically integrate with the goals of education, enter the content of all academic disciplines, be present in all forms of training and become an active mechanism of the national education system to form a Russian citizen, contributing to its socialization and integration into society.

It happened historically that in the domestic system of social education, upbringing always determined learning. The organic unity (integration) of education and upbringing allowed the Russian people to create a great unique culture, a man of extraordinary spiritual beauty. His best qualities: mercy, compassion, sympathy, spirituality, sacrifice, communality, collectivism. All these qualities were formed (brought up) by the whole system of domestic social education (parents, community, society). Russian people, despite all the historical upheavals (constant wars, rebellions, natural elements), managed to overcome everything with their spirit and created character, to master enormous natural spaces, to build a strong state, to create one of the best education systems in the world (Soviet).

3. Transition in the system of secondary and higher vocational education from the narrow specialized training of specialists (bachelors, masters, specialists) of all spheres of the economy of the Russian Federation to a broader professional level. This implies a transition to a new educational paradigm that will allow organizing professional training on completely new ideas about a specialist of modern times. This educational paradigm presupposes the organization of professional training at the intersection of many sciences. The future specialist of any direction (profile) should have: high culture and creative intelligence; know at least three languages; be good at programming; master communicative technologies; understand the meanings and values of one's own and other national cultures; possess the skills and abilities of independent mastering of new information, its analysis; be able to predict the development of the situation in its field of activity; develop appropriate programs and technologies to solve emerging problems, implement them; have a high level of spirituality.

The development of scientific industries and areas today is going along geometric progression. Leading world scientists, experts and analysts already see the future of the planet Earth clearly. Many countries in the world make futuristic forecasts of the development of their state and society, make long-term concepts and strategies (for 50-100 years) about the development of all spheres of the economy, including the institution of education, identify possible professions and ways of their training (USA, China, Korea, Japan, India and other countries).
Today the pace of life is so high that it causes some concern for medical scientists and psychologists, who note not only a violation of the health of the younger generation, but also a change in the human psyche, the emergence of new forms of mental disorders associated with manifestations of social deviations. Increasing socio-cultural dynamics, the growth of information flows, the emergence of all new technologies force the scientists-teachers to revise the existing educational programs almost every year, to make appropriate adjustments to them, to pay more attention to the institution of education, and to take it into account in the development of educational standards and programs at all levels of the education system.

The future, as new trends and innovations, scientific discoveries and futuristic forecasts entered human life, began to exert a total influence on the formation of image and style of life of modern man, the development of all spheres of lifebuilding (family, politics, sports, education, professional activity, leisure). Its manifestation was actively expressed in the development of personal and professional characteristics of man, especially of the younger generation.

\section{CONCLUSIONS}

In general, it can be said that the future has come so close to the present that it has begun to determine the format of the development of modern civilization. So the Russian Agency for Strategic Initiatives has already prepared an atlas of the professions of the future, which represents the world of professions that will be most in demand in the short term. Experts believe that in the near future (20-30 years), many professions will simply cease to exist (up to 50\%), people in many professional activities will be replaced by smart robots.

As for the professions of the education sector, some scientists believe that teachers will be replaced by new specialists - game players, including smart robots, capable of not only controlling behavior and actions of the child, playing with him, but also training him in the appropriate programs. In this direction, European and Japanese scientists are actively working, which have already had quite good analogues of "robot-teachers".

How much realistic and promising this direction in the system of human education, its upbringing, development, adaptation and socialization is a debatable and controversial issue. This question lies in the area of futuristic forecasts for the development of human civilization. In one of the authors' articles, they considered this problem, where they proposed three variants of the development of human civilization $[10,11]$. This is the way of the noosphere, the way of the cyber civilization, the way of the necrosphere (stagnation). Each variant of the way has the possibility of its realization and assumes its own philosophy of the life organization of humankind. The cyber civilization has a philosophy of life organization that assumes constant progress based on market economy and consumption of natural material goods. Scientific progress is aimed at maximum use of technological achievements, artificial reconstruction of the destroyed nature and human health. It is the cyber civilization that assumes maximum use in the educational system of all kinds of educational and upbringing technologies, where the main 
functions of the teacher will be performed by special robots. The man of such a society will carry all the signs, qualities and properties of the cyber civilization in himself. The concepts of 'spirituality' and 'morality' will be completely replaced by the 'universal ethics of rationality', which fully corresponds to the philosophy of the development of the cyber civilization.

There is a hope that Russia and all humankind will choose the way of noospheric development, where science and education in their integration with the spiritual essence of man will act as an intelligent force based on the highest spiritual meanings and values worked out by all world cultures.

\section{References}

[1] A.M. Egorychev, "Russia and the world civilization of the beginning of the XXI century: philosophical and socio-cultural foundations of building a strategy for social development," Scientific Notes, Vol.14, 1(128), pp. 78-89, 2015

[2] V.N. Maksimova, "Integration in the education system," St. Petersburg: LONRO, 2000.
[3] N.N. Malofeev, "The modern concept of 'integration': term and meaning," In Theses of International Seminar: Actual problems of teaching, adaptation and integration of children with developmental disabilities, St. Petersburg, pp. 41-43, 1995.

[4] L.A. Tikhomirov, "State, freedom and Christianity," Simferopol, 1912.

[5] V.D. Belikov, S.I. Chetverikova-Belikova, "Milestones of the history of Russia, Buenos Aires," Novosibirsk, p. 97, 2006.

[6] L.A. Tikhomirov, "Monarchical Statehood," Moscow, republished, 1992.

[7] V.I. Vernadsky, "Biosphere and noosphere," Moscow: Nauka, 1989.

[8] G. Malkov, "Church and monarchy: an assignment for Russia," Tribune of Russian thought, 12, p. 208, 2009.

[9] A.M. Mityaeva, "Integration in vocational training of students in conditions of modernization of education," Education and society, 3(98), pp.15-18, 2016.

[10] D.V. Shamsutdinova, "Leisure activities as a factor of socio-cultural integration of the individual," [PhD Theses], St. Petersburg: Kazan State University of Culture and Arts, 2002.

[11] A.M.Mityaeva, E.N. Puzankova, A.M. Egorychev, S.N. Fomina, and V.N. Pravdyuk, "Interethmc communication and interaction of students in their professional training," Social Sciences (Pakistan), vol. 11, 27, pp. 856-861, 2016. 